\title{
Denis, P (ed) 1997 - Facing the crisis: Selected texts of Archbishop D E Hurley
}

Pietermaritzburg: Cluster Publications. Paperback, 282 pages. Price: Unknown.

\section{Reviewer: Dr Gafie van Wyk}

The editor of this volume of essays by Archbishop Denis Hurley wants to contribute to a better knowledge of the life and ministry of Hurley. The book is dedicated to Hurley to commemorate a half century of episcopate. Hurley is well known. His reputation has gone far beyond the boundaries of South Africa, not only as an opponent of the segregation politics of the previous South African state, but also as a theologian, particularly after the Second Vatican Council, in which he participated actively. The volume includes 23 items written by Hurley between 1960 and 1996 and two biographical essays by Frederick Amoore and Philippe Denis. A bibliography of Hurley, compiled by Joy Brain, completes the volume.

One can only begin to understand Hurley's social and political comments when their theological context is taken into account. In the first place Hurley is a theologian and advocate of the historical method of presentation. He explains his point of view in an essay on the Pastoral emphasis in Seminary Studies:

The historical emphasis will restore the sacred Scriptures to their rightful place in the heart of theology and the stress on experience will require that all theology be oriented towards personal and community growth in holiness and practical formation for the pastoral ministry .... Scripture would be clearly seen as the source and the substance of the whole doctrinal flow. It would not be reduced to a collection of disjointed texts. The opinions and interpretations of the Fathers and the magisterial decrees of the popes and the councils would be dealt within the context of history. Scholastic analysis would be demonstrated and its importance appreciated for the careful definition and preservation of theological thought. The effect of the Reformation would be assessed, the Catholic position clarified and an "ecumenical" approach suggested. Finally the treatment would be rounded out with a demonstration of the significance of the treatise for the spiritual life and its relevance to the doctrinal, liturgical and apostolic renewal of our times ( $\mathrm{p} 22-23)$.

The theologian's concern when applying the historical method must not be for the salvation of individual souls, but rather for the growth of Christ's kingdom and the salvation of God's people, individual and community, soul and body. This means that Hurley concentrates in his theology on the classic Roman Catholic question of the relation between revelation and reality (p 21). Within the modern political context Hurley gives a specific answer to the question at stake. He says: "It is true that the Church does not wish to be confused with civil society. But it does wish to have an influence on civil society, because it seeks to concentrate all human activity, forming Christian consciences in such a way that people as citizens and as leaders of the earthly city can imprint a Christian direction upon social and political life." Hurley knows that by defending this position of freedom of the Church, it will hardly be possible to avoid conflict with civil authority. Because this conflict cannot be avoided, the difficulty for the Church will be to conduct itself in the conflict as the witness to the love of Christ. The Church cannot tolerate injustices committed or permitted by the public authority against people, particularly injustices against the poor. "The Church must raise its voice against such abuses of power, and it will at times come into conflict with civil powers, but without ever ceasing to bear witness to Christ's love" (p 35). 
Hurley's theological position did not only bring him into conflict with the previous South African state, but also with the Calvinistic Afrikaans-speaking Churches. In 1960 Hurley spoke out against these Churches with the following argument:

The Afrikaner is concerned not only about his colour but also about his nation and is involved in a ceaseless campaign of national preservation and self-assertion. Religion plays an important part in that struggle. Afrikaner Calvinism is an ingredient of the national spirit, providing it with a sense of divine mission. The man who sets his face grimly to do what he understands to be God's manifest will for his race is capable of swallowing any apartheid horror with a clear conscience. That is the tragedy of political Calvinism (p 8).

Hurley is fair in his analysis of the social problems of apartheid South Africa. He does not blame the Afrikaners as a group for all the problems of apartheid, because he is prepared to analyse apartheid against the background of Anglo-European colonisation and admit the guild of his own Church in this regard. He says: "We are hypocrites if we condemn apartheid in South African society and condone it in our own institutions" ( $p$ 10). The solution he proposes for apartheid is "a national policy based on human rights, the common good and the dignity of man rather than on sectional interests" (p 11).

This very short resume of the relation between the fundamental theological thought of Hurley and his critique of the South African society is no more than an attempt to stimulate interest in the texts published in this volume. This publication is aimed at Roman Catholic readers in the first place, but it will also appeal to a wider audience. Anyone interested in contemporary thought in the Roman Catholic Church, social critique in South African society and ecumenical theology will find the book interesting. Protestant theologians might as well take note of Hurley's writings. Denis Hurley is surely a remarkable man who confronts his readers with real problems and often impressive solutions to these problems. 